\title{
PERLINDUNGAN KONSUMEN DALAM PELABELAN PRODUK MENURUT EKONOMI ISLAM
}

\author{
Mitta Muthia Wangsi ${ }^{1}$, Rais Dera Pua Rawi ${ }^{2}$ \\ Pengajar di Universitas Muhammadiyah Sorong \\ E-Mail: mithamuthia@gmail.com
}

\begin{abstract}
Abstrak
Jenis penelitian ini adalah penelitian literer yaitu menggunakan buku - buku yang berkaitan dengan judul di atas. Sedangkan pendekatan yang digunakan adalah pendekatan kualitatif. Dengan metode pengumpulan data yang berkaitan dengan materi pembahasan penulis menggunakan dokumenter. Dalam analisis data penulis menggunakan metode induktif dan deduktif yang kemudian dianalisa dengan menggunakan metode analitis deskriptif. Peneliti memperoleh hasil penelitian bahwa legalitas perundang-undangan perlindungan konsumen di indonesia telah diadopsi dari adanya peran ekonomi islam dalam menciptakan kesejahteraan para pelaku ekonomi yang berasaskan pada Al-Qur'an, Hadist dan penerapannya sejak zaman kekhilafahan. perlindungan konsumen merupakan salah satu upaya dalam penerapan pelaksanaan Ekonomi Islam untuk melindungi konsumen dan untuk memberikan rasa tanggung jawab kepada para pelaku usaha dalam setiap kegiatan produksi sehingga tercapailah keadilan ekonomi dalam setiap kegiatan pemenuhan kebutuhan (barang dan jasa). Ada beberapa pihak yang mempunyai peran khusus dalam penerapan konsep perlidungan konsumen dalam pelabelan produk pangan diantaranya : pertama: individu, yaitu setiap orang harus sadar akan keberadaannya masing-masing sebagai pihak konsumen yang berhak mendapatkan hak-haknya dan sebagai pelaku usaha yang harus memperhatikan berbagai tanggung jawab berkaitan dengan produk yang dihasilkan. Kedua: pemerintah, pihak ini bertugas menetapkan peraturan (undang-undang) perlindungan konsumen dan memberikan pengawasan atau kontrol terkait dengan harga, kualitas, kadaluarsa yang tertulis di label suatu produk. Ketiga: lembaga perlindungan konsumen, lembaga swasta ini dibentuk dari beberapa masyarakat yang peduli akan pentingnya perlindungan konsumen demi terpenuhinya hak-hak para konsumen.
\end{abstract}

Kata Kunci: Label Produk, Ekonomi Islam, Perlindungan Konsumen,

\section{PENDAHULUAN}

Tingginya permintaan dan kemajuan teknologi menyebabkan terjadinya peningkatan terhadap barang yang dikonsumsi oleh konsumen. Dan seiring berkembangnya zaman pun menjadikan barang yang dikonsumsi ikut turut meningkat persediaannya. Para konsumen yang dihadapkan oleh banyaknya pilihan dari berbagai jenis dan macam barang adalah akibat dari meningkatnya jumlah dan kualitas barang-barang yang dikonsumsi secara terus menerus.

Sebagai pengonsumsi, konsumen harus bertanggung jawab atas jenis barang yang dikonsumsinya. Adapun hal-hal yang harus diperhatikan konsumen baik dari segi tugas, kewajiban dan haknya dalam mengonsumsi suatu produk adalah sebagai berikut:

A. Tugas Konsumen

a. mengkonfirmasi atau mengecek dari mana sumber barang berasal melalui data yang tercantum pada barang tersebut

b. lebih lama dan teliti untuk memilih item yang akan dikonsumsi dengan tepat (tidak hanya dari harga yang ekonomis).

c. untuk tidak membeli barang yang tidak memiliki kejelasan yang pasti.

d. tidak mudah disesatkan oleh iklan suatu jenis barang.

e. Untuk memastikan dan mengecek isi dan jaminan yang diperoleh dari penjual sebelum membeli item. 
Mitta muthia wangsi ${ }^{1}$ Rais Dera P Rawi ${ }^{2}$

f. memeriksa dan memastikan keamanan dalam mengonsumsi barang tersebut.

g. Pastikan tanggal kadaluwarsa sebelum membeli.

B. Kewajiban Konsumen

a. untuk membaca atau mengetahui informasi yang tertera pada barang atau jasa yang dikonsumsi demi keselamatan dalam pemakaian.

b. bertindak dengan itikad baik dalam melakukan pembelian barang atau jasa.

c. membayar sesuai dengan nilai tukar yang telah disepakati.

d. menegakkan hukum perlindungan konsumen.

C. Hak Konsumen

a. Hak untuk kenyamanan, keamanan dan keselamatan barang dan jasa.

b. Hak untuk memilih barang atau jasa, sesuai dengan nilai tukar, persyaratan dan jaminan.

c. hak atas informasi yang benar, jelas dan jujur mengenai barang atau jasa

d. hak untuk memperoleh bimbingan dan kesadaran sebagai konsumen.

e. Hak atas kompensasi atau penggantian apabila barang atau jasa yang diinginkan tidak sesuai.

Meskipun perlindungan konsumen telah dijamin dalam undang-undang Republik Indonesia Nomor 8 Tahun 1999, namun masih saja ditemukan adamya kecurangan-kecurangan yang dilakukan oleh pelaku usaha dimana barang-barang yang diproduksi memiliki deskripsi yang berbeda dari gambaran aslinya. Brand terkenal Ajinomoto memasarkan produknya yang dicampur dengan campuran haram yakni lemak babi, tidak memberi keterangan halal pada kemasan produknya. Obat anti nyamuk HIT ketika belum ditarik dari pasaran (2006), diketahui memasarkan produknya yang mengandung zat berbahaya bagi kesehatan manusia, yaitu zat pestisida. Biskuit GABISCO dipasarkan dalam keadaan tercampur racun anion nitrit dan mengakibatkan beberapa konsumen meninggal dunia (1989).

Oleh karena itulah mengapa dibutuhkannya kejelasan label, himbauan, dan peringatan kepada konsumen guna memberitahukan perihal barang atau jasa yang mungkin bertentangan dengan realitas dan kebenaran. Hal ini pula yang menjadikan konsumen dituntut untuk mampu mengetahui dan memilih jenis barang terbaik yang dikonsumsinya mengingat pelaku dalam kegiatan jual beli bukanlah hanya pihak produsen saja namun juga konsumen. Dan hadirnya perlindungan konsumen dalam ekonomi Islam salah satunya dapat diartikan sebagai sebuah gerakan yang terorganisir untuk melindungi kepentingan ekonomi semua kalangan konsumen (muslim dan nonmuslim) yang dipraktekkan ke berbagai lembaga pemerintah dan non-pemerintah yang bertujuan untuk menjamin hak-hak konsumen sehubungan dengan barang dan jasa (yang baik dan bermanfaat), mencakup informasi yang diinginkan dan sesuai dengan legitimasi, serta tidak hanya perlindungan konsumen dalam pemasaran barang dan jasa namun juga meluas ke tahap perlindungan konsumen dalam kegiatan produksi.

Tujuan dari penelitian ini adalah untuk mengetahui bagaimana perekonomian Islam melindungi konsumen khususnya dalam pelabelan produk serta penerapannya dalam pandangan ekonomi islam karena pada dasarnya ekonomi islam hadir dengan perannya dalam memberikan rasa keadilan bagi para pelaku perdagangan, yaitu ketelitian bagi konsumen dalam mengonsumsi suatu produk dan pentingnya rasa tanggung jawab bagi pelaku usaha dalam memproduksi suatu jenis barang.

\section{METODE PENELITIAN}

\section{A. Jenis dan Sumber Data}

Jenis penelitian ini merupakan jenis Penelitian Pustaka (Library Research), yaitu suatu usaha memperoleh data dan 
PERLINDUNGAN KONSUMEN DALAM PELABELAN PRODUK......

Mitta muthia wangsi ${ }^{1}$ Rais Dera P Rawi ${ }^{2}$

informasi yang dibutuhkan atau diperlukan dengan cara menganalisis suatu permasalahan melalui sumber-sumber pustaka yang kemudian dijadikan sebagai landasan teori.

Dalam pengumpulan data, penelitian ini menggunakan data-data kualitatif yang mana data dikumpulkan dari Data Sekunder (Buku-buku atau Literaturliteratur yang berhubungan dengan objek penelitian) dan Dokumentasi (Dokumendokumen yang berkaitan dengan objek yang diteliti).

\section{B. Tekhnik Analisi Data}

Dalam menganalisis data, penelitian ini menggunkan dua metode sebagai berikut:

1. Metode Deduktif, yaitu cara analisis dari kesimpulan umum (berupa teoriteori) menjadi uraian-uraian fakta. Metode deduktif ini menggunakan tahapan-tahapan, yaitu:
a. Tahapan Spekulasi
b. Tahapan observasi dan klasifikasi
c. Tahapan perumusan hipotesis

2. Metode Induktif, cara analisis dari uraian fakta-fakta yang kemudian dirumuskan menjadi suatu kesimpulan umum.

3. Metode Deskriptif Analitis, yaitu memusatkan perhatian kepada masalahmasalah sebagaimana adanya, yang kemudian hasil penelitian diolah dan dianalisis untuk membuat kesimpulan umum.

\section{HASIL DAN PEMBAHASAN}

\section{A. Pengertian perlindungan konsumen dalam Ekonomi Islam}

Perlindungan konsumen dalam ekonomi islam adalah merupakan cara bagaimana ekonomi islam memenuhi kebutuhan konsumen (komunitas muslim) dalam mengonsumsi suatu jenis barang. Dalam konteks ini, bisa juga berarti bagaimana ekonomi islam mengatur produsen dalam kegiatan produksinya menyediakan kualitas barang yang dikonsumsi. Hal ini dilakukan melalui tindakan penerapan sifat pasar yang islami dan terkontrol.

Dengan demikian pengertian Perlindungan konsumen dalam ekonomi Islam dapat diartikan sebagai Sebuah gerakan yang terorganisir untuk melindungi kepentingan ekonomi semua kalangan konsumen (muslim dan nonmuslim) yang dipraktekkan ke berbagai lembaga pemerintah dan non-pemerintah yang bertujuan untuk menjamin hak-hak konsumen sehubungan dengan barang dan jasa yang benar dan bermanfaat mencakup informasi yang diinginkan dan sesuai dengan legitimasi, tidak hanya perlindungan konsumen dalam pemasaran barang dan jasa namun juga meluas ke tahap perlindungan konsumen dalam kegiatan produksi.

\section{B. Pembentukan}

Perlindungan

\section{konsumen dalam Ekonomi Islam}

Perlindungan konsumen dalam ekonomi islam sudah sering disebut semenjak periode antara tahun $1 \mathrm{H}$ sampai dengan tahun $40 \mathrm{H}$ yang merupakan periode berdirinya Negara islam dan juga pembentukan basis legislative dimana di dalamnya diwujudkan prinsip - prinsip islam dalam semua urusan kehidupan dan tingkat budaya masyarakat dari waktu ke waktu.

Pembentukan perlindungan konsumen ini didasarkan pada penjelasan dalam Al-Qur'an dan As-Sunnah sebagai berikut:

a. Perlindungan konsumen berasaskan penjelasan Al-Qur'an

Allah telah menjelaskan dalam kitab suci Nya berbagai ketentuan yang ditujukan kepada hamba Nya dalam mengonsumsi suatu jenis barang, misalnya : 
Mitta muthia wangsi ${ }^{1}$ Rais Dera P Rawi ${ }^{2}$

1. Untuk mencegah Algish (kecurangan) perihal keseimbangan takaran.

"Dan wahai kaumku! Penuhilah takaran dan timbangan dengan adil, dan janganlah kamu merugikan manusia terhadap hak-hak mereka..."

(Q.S Hud, Ayat 85)

2. Untuk mencegah terjadinya

Riba

"Dan karena mereka menjalankan riba, padahal sungguh mereka telah dilarang darinya..." (Q.S An-Nisa, Ayat 161)

Maksudnya riba disini (dalam hal perlindungan konsumen) adalah dalam hal penambahan, yaitu menambahkan apa-apa yang sebenarnya tidak ada pada barang tersebut untuk menarik konsumen agar mengonsumsinya.

b. Perlindungan konsumen

berasaskan hadist

Mengenai perlindungan

konsumen juga telah di

jelaskan berbagai

ketentuannya dalam hadist

Nabi, diantaranya:

1. Untuk mencegah

Dari Abu Hurairah R.A berkata "Rasulullah SAW melarang jual beli anak-anak batu dan jual beli gharar" (H.R.Muslim).

Maksud jual beli anak batu di sini adalah anak batu atas barang yang kena itulah yang akan dijual. Contoh: penjualan tanah yang dilakukan pada jaman islam dulu berdasarkan berhentinya anak batu yang dilempar (jauh atau dekatnya tidak bisa dipastikan). Karena adanya ketidak pastian inilah maka jual beli tersebut dilarang dalam islam. Begitu juga dengan gharar, yaitu jual beli yang kadar ukuran, berat dan jenisnya belum diketahui.
Dari penjelasan hadist tersebut telah diterangkan bahwa dalam penjualan suatu jenis barang apapun haruslah disertai dengan kejelasan barang tersebut (jenis, ukuran, berat, dan isi).

2. Opsi legalisasi

"Dari Amr bin Syu'aib dari bapaknya dari kakeknya bahwa Rasulullah saw bersabda, "pembeli dan penjual (mempunyai) hak khiyar atau memilih selama mereka belum berpisah (pembeli belum meninggalkan tempat jual beli atau penjual)...." (H.R.Khomsah).

Khiyar atau memilih disini merupakan hak yang sudah ada pada konsumen sejak zaman Rasulullah dan menjadi rukun jual beli dalam ekonomi islam. Oleh karena itulah hak ini harus digunakan sebaik-baiknya oleh konsumen dalam memilih barang yang akan dikonsumsinya. Dan dalam mengonsumsi barangpun konsumen harus menyertakan ketelitian dalam memilih suatu jenis produk barang tersebut.

c. Perlindungan konsumen

berasaskan pada khilafah

Para khulafaur Rasyidin memegang peran penting dalam menyusun aturan dalam melindungi konsumen, dan hal paling penting tersebut itu perlu bagi kita untuk meneladaninya. Contoh dan aturan ini adalah sebagai berikut:

1. Khalifah Abu Bakar As-Shiddiq menerapkan batas nominal peredaran uang publik dan rasionalisasi konsumsi perkapita (dalam mengonsumsi barang).

2. Khalifah Umar bin al-Khattab menetapkan norma bagi konsumen guna untuk melindungi dirinya dari pedagang dan pelaku ekonomi lainnya.

3. Khalifa Uthman bin Affan sangat memperhatian pasar, serta 
PERLINDUNGAN KONSUMEN DALAM PELABELAN PRODUK......

Mitta muthia wangsi ${ }^{1}$ Rais Dera P Rawi ${ }^{2}$

menghimbau akan perlunya mempertahankan dana (modal).

4. Khalifa Ali bin Abi Thalib selalu memosisikan sebagai orang yang tepat di tempat yang tepat dalam kegiatan yang berhubungan dengan ekonomi.

d. Perlindungan konsumen berasaskan tujuan syariat islam

Tujuan daripada ketetapan syariat islam yaitu untuk mencapai tujuan dari penerapan syariat yang telah ditetapkan kepadanya setiap hukumnya. Tujuan hukum islam tidak hanya ditujukan kepada satu hal saja, namun ditujukan kepada tiga hal penting yaitu: kebutuhan, keinginan, dan perbaikan (pelengkap). Ketiga hal penting ini selalu disangkutpautkan dengan lima hal berikut:

1. Menjaga agama

2. Menjaga diri

3. Menjaga kesadaran

4. Menjaga keturunan

5. Menjaga harta

Syariah islam datang dengan berbagai ketetapan hukum salah satunya dalam bidang ekonomi untuk selalu menjaga dan menunjang keberadaan lima hal tersebut sebagai serangkaian ketentuan untuk mencapai tujuan diantaranya adalah dalam hal perlindungan konsumen dalam mengonsumsi jenis barang.

\section{Label pada komoditas produk}

\section{Pengertian pelabelan produk}

telah menjadi ketetapan Keputusan Eksekutif No. 90-367 tanggal 1990/10/11 mengenai penandaan komoditas produk, menurut Pasal 2 dari SK tersebut, yang dimaksudkan dengan pelabelan ialah " pemberian data atau instruksi dari pabrik dalam bentuk tanda perdagangan, gambar atau berhubungan dengan komoditas pangan tertentu yang ditempatkan dengan tujuan untuk memobilisasi simbol dokumen atau spanduk atau kartu atau cap yang melekat pada item makanan yang terkait.

\section{Konsep Pelabelan (Branding)}

Dalam peraturan pemerintah Republik Indonesia, Nomor 69 tahun 1999, Pasal 1 mengenai label dan iklan pangan, agar selalu terfokus dalam memahami pelabelan yang mana mencakup informasi tentang makanan tersebut baik dalam bentuk gambar, teks, dan mengenai apa saja yang terkandung di dalamnya (peraturan pemerintah), dan merupakan bagian dari kemasan makanan tersebut. dalam konsep pelabelanpun dibedakan antara komoditas pangan dan komoditas non-pangan:

a. pelabelan komoditas pangan

telah menjadi ketetapan Keputusan Eksekutif No. 90-367 tanggal 1990/10/11 mengenai penandaan komoditas pangan, pandangan, dan menurut Pasal 2 dari SK tersebut, yang dimaksudkan dengan pelabelan ialah " pemberian data atau instruksi dari pabrik dalam bentuk tanda perdagangan, gambar atau berhubungan dengan komoditas pangan tertentu yang ditempatkan dengan tujuan untuk memobilisasi simbol dokumen atau spanduk atau kartu atau cap yang melekat pada item makanan yang terkait.

b. pelabelan komoditas non-pangan

Hal ini mencakup privasi label bahan makanan yang wajib dikumpulkan. Berdasarkan keputusan pasal 6 mengenai proses labelitas komoditas non-pangan perlu diperhatikan beberapa hal sebagai berikut:

1. label tanda pelegalan kegiatan penjualan

2. kuantitas produk

3. Tanggal pembuatan, menyatakan dengan kata-kata "Made in ..." jangka maksimum validitas konsumsi dinyatakan "dikonsumsi oleh ..." serta kondisi produk.

4. Nama atau nama perusahaan atau merek dagang yang terdaftar dan alamat instansi yang bertanggung jawab dalam kegiatan industry,klarifikasi , dan distribusi 
Mitta muthia wangsi ${ }^{1}$ Rais Dera P Rawi ${ }^{2}$

5. Metode penggunaan produk atau kondisi penanganan khusus jika diperlukan

6. Semua data wajib lainnya diatur dalam ketentuan khusus.

Label berperan penting dalam memberikan informasi tambahan mengenai ciri dari semua karakteristik yang terkandung pada suatu barang. Ia bersifat sebagai media yang secara kesempurnaan meliputi hal yang berkaitan dengan kegiatan produksi (industri barang, bahan, serta daerah asal) dan memberikan kepada pembeli banyak pengetahuan tentang bahan dan kualitas produk baik itu yang kualitasnya tinggi ataupun yang kualitasnya biasa. Hal inilah yang membantu para pembeli dalam memilih jenis barang yang beraneka macamnya untuk mereka konsumsi.

\section{c. Jenis dan Sifat Label}

Jika diklasifikasikan jenis label terfokus pada hal yang berkaitan dengan lingkungan, dan persyaratan sosial dan kesehatan, baik dalam bidang manufaktur dan kualitas produk. pada umumnya label dibagi menjadi dua jenis, yaitu:

a. label yang diperoleh melalui badan kepemerintahan, yaitu yang bertanggung jawab untuk penyediaan dan pengawasan label, dan pengembangan standar dan pemberitahuan dengan pihak terkait.

b. Private label, yaitu yang bertanggung jawab dalam penyediaan dan pengawasan label, dan kriteria yang harus dipenuhi oleh format produsen, dan lain-lain. Pada tahap identifikasi standar ini dapat berfungsi sebagai penasihat pemerintah.

Dan berdasarkan sifatnya, label dibagi menjadi dua macam:

a. Label yang bersifat negatif adalah label yang memberikan informasi yang tidak terdapat dari semua karakteristik jenis barang atau jasa sehingga konsumen tidak mampu mengantisipasi hal ini hanya dengan kemampuannya saja.

b. label yang bersifat positif adalah label yang secara komitmen dan berkewajiban memberikan segala informasi sesuai dengan fenomena jenis barang atau jasa tersebut. Karena jika sebelumnya konsumen telah memiliki pengetahuan yang cukup untuk memahami informasi suatu jenis barang maka label pada jenis barang tersebut cukup mampu untuk mempengaruhi keputusan konsumen dalam kegiatan konsumsinya.

Pelabelan komoditas pangan perlu dan harus diperhatikan khususnya oleh para konsumen. Tidak hanya dalam satu hal namun dalam segala hal guna menghindari dari tindakan penipuan. Dan untuk menghindari hal tersebut yang diperhatikan tidaklah hanya dari pihak konsumennya saja, namun juga pihakpihak yang terkait dalam kegiatan produksi. Pelaku usaha memiliki tanggung jawab yang diatur Pemerintah dalam undang-undang Republik Indonesia Nomor 8 Tahun 1999 tentang Perlindungan Konsumen sebagai berikut:

a. memperhatikan berat, ukuran dan jumlah yang tercantum dalam label atau dalam penamaan elemen-elemen tersebut.

b. mencocokan berat atau ukuran sesuai dengan jumlah hitungan sebenarnya.

c. menyertakan kualitas, cara pengolahan, atau cara penggunaan yang dinyatakan dalam label atau keterangan barang atau jasa.

d. memperhatikan label atau iklan dalam mempromosikan jenis barang dalam kegiatan penjualan barang atau jasa.

e. menentukan otoritas atau tanggal penyelesaian dan penggunaan jenis barang atau jasa. 
f. memperhatikan pendekatan terhadap konsumen muslim, seperti dalam pernyataan atau gambar yang termasuk dalam label.

g. memberitahukan perihal barang atau jasa yang rusak atau sudah tidak dapat digunakan yaitu dengan memberikan informasi secara lengkap dan benar atas barang yang bersangkutan.

h. jenis barang yang berkaitan dengan farmasi dan makanan harus memperhatikan hal-hal yang berkaitan dengan gangguan fungsi atau kerusakan pemakaian pada informasi yang benar.

\section{Penerapan perlindungan konsumen dalam pelabelan produk menurut ekonomi islam}

Pasar yang semakin mengglobal dengan adanya berbagai cara dalam bertransaksi menjadikan hubungan pelaku usaha dan konsumen semakin berkembang dan berdampak pada perubahan konstruksi perekonomian.Globalisasi pasar pun turut mendukung tumbuhnya dunia usaha sehingga mampu menghasilkan beraneka ragam barang dan jasa. Keanekaragaman barang dan jasa ini menjadikan Konsumen kurang memperhatikan jenis barang dan jasa yang dikonsumsinya sehingga tidak sedikit dari para pelaku usaha menggunakan kesempatan ini untuk melakukan berbagai kecurangan terhadap produk yang dihasilkannya, baik dalam hal kualitas maupun kuantitas.

Fenomena ini bertentangan dengan perlindungan konsumen dalam ekonomi islam, yaitu tidak adanya kejelasan produk (label) yang menjadikan konsumen berada di pihak yang dirugikan. Karna pada hakikatnya Ekonomi Islam menjaga dan melindungi hak-hak konsumen dalam mengonsumsi suatu produk sehingga dapat turut membantu para pelaku usaha untuk lebih bertanggung jawab dalam kegiatan
Mitta muthia wangsi ${ }^{1}$ Rais Dera P Rawi ${ }^{2}$ berproduksi demi mewujudkan kegiatan perdagangan yang aman bagi kemaslahatan umat.

Legalitas perundang-undangan perlindungan konsumen di indonesia telah diadopsi dari adanya peran ekonomi islam dalam menciptakan kesejahteraan para pelaku ekonomi yang berasaskan pada Al-Qur'an, Hadist dan penerapannya sejak zaman kekhilafahan. Perlindungan konsumen merupakan salah satu upaya dalam penerapan pelaksanaan hukum Ekonomi Islam untuk melindungi konsumen (muslim khususnya) dan untuk memberikan rasa tanggung jawab kepada para pelaku usaha dalam setiap kegiatan produksinya sehingga tercapailah keadilan ekonomi dalam setiap kegiatan pemenuhan kebutuhan (barang dan jasa). Ada beberapa pihak yang mempunyai peran khusus dalam penerapan konsep perlidungan konsumen dalam pelabelan produk diantaranya :

1. Individu,yaitu setiap orang harus sadar akan keberadaannya masingmasing sebagai pihak konsumen yang berhak mendapatkan hakhaknya dan sebagai pelaku usaha yang harus memperhatikan berbagai tanggung jawab berkaitan dengan produk yang dihasilkan.

2. Pemerintah, pihak ini bertugas menetapkan peraturan (undangundang) perlindungan konsumen dan memberikan pengawasan atau kontrol terkait dengan harga, kualitas, kadaluarsa yang tertulis di label suatu produk.

3. Lembaga perlindungan konsumen, lembaga swasta ini dibentuk dari beberapa masyarakat yang peduli akan pentingnya perlindungan konsumen demi terpenuhinya hakhak para konsumen.

Tujuan ekonomi islam mengenai perlindung konsumen yaitu sebagai pembangunan ekonomi masyarakat dan 
untuk mencapai minat konsumen (agar selalu mengonsumsi jenis barang yang baik). Dan perlindungan konsumen dalam ekonomi islam ini terpusat pada beberapa hal berikut:

1. Jaminan sosial, yaitu terus berkomitmen untuk memberikan kepada setiap individu dalam kalangan masyarakat standar hidup yang layak (keamanan mengonsumsi barang dan jasa) dalam memenuhi kebutuhannya agar dapat mencapai ridha Nya.

2. Mencapai pembangunan ekonomi, yaitu melakukan pembangunan ekonomi Islam sesuai dengan syariat guna sebagai rekonstruksi dunia karna dianggap sebagai tugas (khalifah di bumi) dan sekaligus sebagai ibadah.

3. Keseimbangan ekonomi antara individu, keseimbangan di sini mengandung arti membuat setiap individu agar selalu berdekatan bahkan sama dalam acuan tingkat perekonomian.

4. Pekerjaan yang optimal, yaitu diharapkan bahwa sistem ekonomi Islam mampu mengatasi masalah perekonomian (khususnya pengangguran) yang melanda banyak Negara islam di dunia saat ini.

5. Stabilitas ekonomi, yaitu selalu berusaha dalam menghindari dan mengatasi situasi perekonomian nasional yang terkandang tidak seimbang akibat dari resesi dan inflasi serta ketidak adilan dari para pelaku ekonomi yang selalu berputar pada kegiatan perekonomian.

\section{KESIMPULAN}

Perlindungan konsumen dalam ekonomi Islam dapat diartikan sebagai Sebuah gerakan yang terorganisir untuk melindungi kepentingan
Mitta muthia wangsi ${ }^{1}$ Rais Dera P Rawi ${ }^{2}$ ekonomi semua kalangan konsumen (muslim dan non-muuslim) yang dipraktekkan ke berbagai lembaga pemerintah dan non-pemerintah yang bertujuan untuk menjamin hak-hak konsumen sehubungan dengan barang dan jasa yang benar dan bermanfaat mencakup informasi yang diinginkan dan sesuai dengan legitimasi, tidak hanya perlindungan konsumen dalam pemasaran barang dan jasa namun juga meluas ke tahap perlindungan konsumen dalam kegiatan produksi.

Tujuan ekonomi islam ditujukan terutama mengenai perihal perlindung konsumen yaitu untuk sebagai pembangunan ekonomi masyarakat dan untuk mencapai minat konsumen (agar selalu mengonsumsi jenis barang yang baik). Dan perlindungan konsumen dalam ekonomi islam ini di terpusat pada beberapa hal berikut:

1. Jaminan sosial

2. mencapai pembangunan ekonomi,

3. keseimbangan ekonomi antara individu

4. pekerjaan yang optimal

5. stabilitas ekonomi

Pelabelan komoditas pangan perlu dan harus diperhatikan khususnya oleh para konsumen Muslim. Tidak hanya dalam satu hal namun dalam segala hal guna menghindari dari tindakan penipuan. Dan untuk menghindari hal tersebut yang diperhatikan tidaklah hanya dari pihak konsumennya saja (mencakup tugas, hak, dan kewajiban konsumen) namun juga dari pihak pemerintah (mencakup kewajiban yang harus diperhatikan dalam kegiatan ekonomi).

\section{REFERENSI}

Husni Syawali, Neni Sri Imaniyati. 2000. Hukum Perlindungan Konsumen.Bandung: Mandar Maju 
Muhammad, Alimin. 2004 Etika Mitta muthia wangsi ${ }^{1}$ Rais Dera P Rawi ${ }^{2}$

\&Perlindungan Konsumen dalam Ekonomi Islam.Jogjakarta: BPFEYOGYAKARTA.

Petra Widmer, Heinz Frick. 2007.Hak Konsumen dan Ekolabel. Jogjakarta: Kanisius.

Undang - Undang R.I No.8 Tahun 1999 Tentang Perlindungan Konsumen. 2010.

Bandung :Citra Umbara.

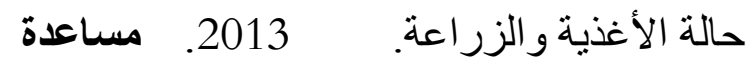

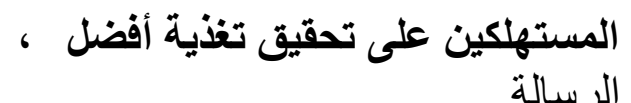

علال الفاسي. 1411هـ1991 م. مقاصد الثريعة

الاستلامية ومكارمها ـ الدار البيضاء: ماهدي

مطبعة النجاح الجديدة.

غازي عناية ـ 2002م. موسوعة الاقتصاد

الإسلامي (الخصائص العامة). الأردن :

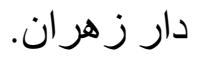

نجاح ميدني. 2007. آلية حماية المستهلك في

الاقتصاد الإسلامي، مذكرة مقدمة لنيل

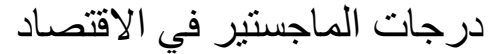

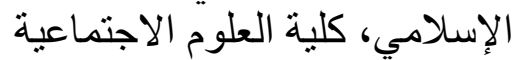

و العلوم الإسلامية. جامعة الحاج

ل ت الخضر.

و هبة الزحيلي، أصول الفقه الإسلامي. الجزائر: دار الفكر، دط، دت، جل، اهول

يوسف حامد العالم. المقاصد العامة للشريعة الإسلامية. القاهرة: دار الحديث،

الخرطوم: الدار السودانية.

سالم محمد عبود، حقوق المستهلك ومنهجية

حمايته مدخل حضاري مع الإثارة

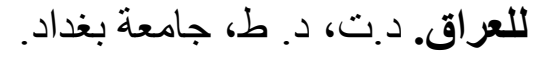

